\title{
Pembelajaran Ilmu Falak di Fakultas Agama Islam Universitas Muhammadiyah Sumatera Utara
}

\author{
Munawir Pasaribu ${ }^{1}$ \\ Universitas Muhamadiyah Sumatera Utara \\ 1Email: munawirpasaribu@umsu.ac.id
}

\begin{abstract}
Astronomy learning is carried out by the exact study program or science and technology study program. When viewed from the study program in Islamic tertiary institutions, namely UIN, IAIN or PTKIS, this science learning is under the Sharia faculty. There are very low applicants who wish to enter this study program. Although it is known that science is studied by certain study programs, there are some faculties that make science one of the faculty compulsory subjects, such as at the Faculty of Islam, Muhamamdiyah University of North Sumatra. This study found that astronomy learning for students was very fun and the learning material was not difficult, the lecturers who taught the subjects were in accordance with their expertise.
\end{abstract}

\section{Keyword: Falak Science, Learning}

\begin{tabular}{l}
\hline Abstrak \\
\hline Pembelajaran ilmu falak dilaksanakan oleh program studi \\
eksakta atau program studi sainstek. Jika dilihat dari program \\
studi di lingkungan perguruan tinggi Islam yaitu UIN, IAIN \\
atau PTKIS maka pembelajaran ilmu falak ini di bawah fakultas \\
Syariah. Peminat yang ingin masuk dalam program studi ini \\
sangat rendah. Walaupun diketahui ilmu falak dipelajari oleh \\
program studi tertentu namun ada dibeberapa fakultas \\
menjadikan ilmu falak salah satu mata kuliah wajib fakultas, \\
seperti di Fakultas Agama Islam Universitas Muhamamdiyah \\
Sumatera Utara. Penelitian ini menemukan bahwa pembelajaran \\
ilmu falak bagi mahasiswa sangat menyenangkan dan materi \\
pembelajarannya tidaklah sulit, dosen pengampu mata \\
kuliahnya sesuai dengan keahliannya.
\end{tabular}

Kata kunci: Ilmu Falak, Pembelajaran. 


\section{AL-MARSHAD: JURNAL ASTRONOMI ISLAM DAN ILMU-ILMU BERKAITAN \\ ISSN 2442-5729 (print) || ISSN 2598-2559 (online) \\ http://jurnal.umsu.ac.id/index.php/almarshad \\ DOI: 10.30596/jam.v\%vi\%i.5251|| Vol. 6, No. 2 Desember 2020}

\section{A. Pendahuluan}

Pembelajaran ilmu falak merupakan ilmu yang sangat urgen dipelajari oleh setiap orang. Ilmu falak sering juga dikatakan ilmu perbintangan atau ilmu tentang hisab karena itulah ilmu ini sangat mempunyai peranan penting dalam kehidupan masyarakat. Kurikulum ilmu falak ini biasanya sudah ditentukan oleh fakultas atau program studi. Selain kepentingan dalam mengetahui ilmu ilmu astronomi, ilmu falak juga sangat mempunyai peran penting dalam penentuan ibadah dengan baik yaitu penetuan arah kiblat dengan baik.

Dari pemaparan peranan penting yang telah diterangkan diatas Susiknan selaku pakar ilmu falak mengatakan setidaknya ada dua kepentingan yang saling mengikat dalam mempelajari ilmu falak ini, Pertama perlu mempelajari ilmu falak dikarenakan bisa menguasai ilmu pengetahuan dan teknologi, kedua untuk keperluan yang ada kaitannya dengan ibadah manusia berupa sholat yaitu dalam penetuan waktunya serta penetapan arah kiblat, dan menetukan waktu-waktu yang berkaitan dengan bulan hijriyah ${ }^{1}$.

Korelasi penjabaran Susiknan

1 Susiknan Azhari, Ilmu Falak Perjumpaan Khazanah Isam dan Sains Modern, Yogyakarta: Suara Muhammadiyah, 2004. h.3 dengan penelitian yang dilakukan muslim

klasik mengenai ilmu falak merupakan salah satu ciri kemajuan peradaban Islam. Walaupun sebagian para ilmuan muslim menempatkan ilmu falak hanya sekedar mengkaji persoalan-persoalan ibadah , seperti arah kiblat, waktu shalat dan awal bulan Qamariah. Sebenarnya dalam perjalannya fase Islam ditandai dengan proses penterjemahan karya - karya monumental dari bangsa Yunani yang sangat mempengaruhi perkembangan ilmu falak di dunia Islam adalah The Sphere in Movement (Al-Kurrah al-Mutharrikah) karya Antolycus, Ascentions of the Signs (Matali' al- Buruj ) karya Aratus , Introduction to Atronomy (Al-Madkhhal ila Ilmi al - Falak ) karya Hipparchus, dan Almagesti karya Ptolomeua ${ }^{2}$.

Jika diteliti Sejarah awal perkembangan ilmu falak di Indonesia pada awalnya perkembangan awal ilmu falak di Indonesia dimulai dari adopsian sistem penanggalan hijriah ke dalam penanggalan Jawa yang dilakukan oleh sultan Agung. Pada tahun 1625 Masehi, Sultan Agung yang berusaha keras menyebarkan agama Islam di pulau Jawa dalam kerangka negara Mataram mengeluarkan dekrit untuk

\footnotetext{
2 Yahya asy-Syami, ,1997, 'Ilm al-Falak, Beirut: Dar al-Fikr 'Arabi,1997, h 125.
} 


\section{AL-MARSHAD: JURNAL ASTRONOMI ISLAM DAN ILMU-ILMU BERKAITAN \\ ISSN 2442-5729 (print) || ISSN 2598-2559 (online) \\ http://jurnal.umsu.ac.id/index.php/almarshad \\ DOI: 10.30596/jam.v\%vi\%i.5251|| Vol. 6, No. 2 Desember 2020}

mengubah penanggalan Saka. Sejak saat itu

kalender Jawa versi Mataram menggunakan sistem kalender kamariah atau lunar ${ }^{3}$.

Pemaparan dari beberapa pakar ahli dan sejarawan diatas jika dikaji di era kemajuan sains dan teknologi hari ini, khususnya dalam bidang pendidikan menuntut adanya inovasi dan improvisasi dalam berbagai bidang ilmu. Inovasi dalam bidang pendidikan hari ini terbilang cukup banyak dan menjanjikan. Belakangan ini baik di tingkat sekolah maupun perguruan tinggi, telah ada inisiasi pengadaan sarana pendidikan unik dan khusus bernama observatorium ${ }^{4}$.

Terkhusus di Universitas

Muhamamdiyah Sumatera Utara salah satu bidang kajian ilmu falak berdiri sebuah tempat kajian-kajian ilmiyah yang membahas tentang berbagai jenis dalam keilmuan ilmu falak yang disebut dengan Ovservatorium Ilmu Falak (OIF UMSU). Sejak berdiri tahun 2014 yang lalu, Observatorium Ilmu Falak Universitas Muhammadiyah Sumatera Utara (OIF UMSU) yang berpusat di Gedung Pascasarjana Lantai 7 Jalan Denai No. 217 Medan terus melakukan berbagai aktifitas

3 Muhyidin Khazin, Ilmu Falak Dalam Teori dan Praktik. Yogyakarta: Buana Pustaka, 2008, h. 28

${ }^{4}$ Akrim, 2020 , Nilai-Nilai Pendidikan Islam dalam Observatorium, Al-Marshad: Jurnal Astronomi Islam Dan Ilmu-Ilmu Berkaitan, Medan 2020. keummatan. Antara lain pengamatan Momen

Rashdul Kiblat, observasi Hilal awal Sya'ban, Seminar Nasional, mendaki Gunung Sibayak hingga meluncurkan roket air, dan lain-lain ${ }^{5}$.

Melihat beberapa analisis para ahli dan kajian terkait dengan perkembangan ilmu falak terkhsusunya di Universitas Muhammadiyah Sumatera Utara, maka jika dilihat dari beberapa fakultas yang ada di lingkungan Universitas Muhammadiyah Sumatera Utara maka bisa dilihat dari keterkaitan materi dan rumpun ilmu yang dikaji mengenai ilmu falak ini maka, cuma Fakultas Agama Islam saja lah yang cocok dalam mengkaji ilmu falak di Universitas Muhamamdiyah Sumatera Utara.

Walaupun diketahui bahwa Fakultas Agama Islam Universitas Muhammadiyah Sumatera Utara ini tidaklah memiliki program studi syariah, atau program studi ilmu falak, namun di Fakultas ini ada materi berupa mata kuliah ilmu falak yang di pelajari pada semester delapan di setiap jurusan yang ada di Fakultas Agama Islam Universitas Muhamamdiyah Sumatera Utara.

Jika dilihat bidang studi ilmu falak di

\footnotetext{
5 Syahril Rambe, Ali Imran Sinaga, Syaukani, 2019, Peranan Observatorium Ilmu Falak Umsu Dalam Pendidikan Islam Di Kota Medan, At-Tazakki: Vol. 3 No. 1 Januari - Juni 2019.
} 


\section{AL-MARSHAD: JURNAL ASTRONOMI ISLAM DAN ILMU-ILMU BERKAITAN \\ ISSN 2442-5729 (print) || ISSN 2598-2559 (online) \\ http://jurnal.umsu.ac.id/index.php/almarshad \\ DOI: 10.30596/jam.v\%vi\%i.5251|| Vol. 6, No. 2 Desember 2020}

ajarkan di Fakultas Agama Islam ini, timbul sebuah keinginanan untuk meneliti lebih jauh bagaimana pengkajian Ilmu Falak di Universitas Muhammadiyah Sumatera Utara sehingga menimbulkan beberapa pokok fokus pertanyaan permasalahan yang akan dikaji dalam penelitian ini diantaranya adalah ; 1) Bagaimana peranan kurikulum ilmu falak di Fakultas Agama Islam. 2) Bagaimana pembelajaran ilmu falak di Fakultas Agama Islam. 3) Peranan pimpinan Fakultas dalam pengembangan Ilmu Falak di Fakultas Agama Islam

\section{B. Metode Penelitian}

Jenis Penelitian ini adalah kualitatif deskriftif dengan pendekatan studi kasus. Dimana beberapa hasil dari penelitian ini akan dilakukan penjelasan demi penjelasan untuk mengungkap pertanyaan dalam beberapa permasalahan yang akan dikaji didalam penelitian ini adapun tujuan dalam penelitian kualitatif ini adalah ingin menggambarkan kenyataan yang ada atau yang terjadi pada objek yang diteliti yaitu menggambarkan bagaimana pembelajaran ilmu falak di Fakultas Agama Islam. Penelitian deskriptif atau disebut juga dengan penelitian pra eksperimen ini dilakukan dalam bentuk kegiatan eksplorasi berupa mengungkap yaitu bagaimana proses pembelajaran ilmu falak dan juga bagaimana respons dari mahasiswa dalam mempelajari ilmu falak, mendeskripsikan fakta berdasarkan keadaan rielnya berupa bagaimana sebenarnya pembelajaran ilmu falak serta dukungan dari pimpinan fakultas dalam menyajikan materi ilmu falak di Fakultas Agama Islam6.

Dalam pernyataannya Moleong mengatakan bahwa penelitian kualitatif berakar pada akar alamiah sebagai keutuhan. Mengandalkan manusia sebagai alat penelitian, memanfaatkan metode kualitatif, mengadakan analisis data secara induktif, mengarahkan sasaran penelitiannya pada usaha menemukan teori dari dasar, bersifat deskriptif, lebih mementingkan proses daripada hasil, membatasi studi dengan fokus, memiliki seperangkat kriteria untuk memeriksa keabsahan data, rancangan penelitiannya bersifat sementara, dan hasil penelitiannya disepakati oleh kedua belah pihak, yakni peneliti dan subjek peneliti ${ }^{7}$.

Dalam penelitian ini, peneliti menggunakan teknik purposive sampling. Purposive sampling adalah salah satu teknik pengambilan sampel yang sering digunakan

\footnotetext{
${ }^{6}$ John W Creswell, Vicki L Plnao Clark, Mendesain dan Melaksanakan Mixed Methods Research. Terjemah Ahmad Lintang (Yogyakarta : Pustaka Pelajar) 2018, h. 214

${ }^{7}$ Lexy. J. Moleong, Metode Penelitian Kualitatif, (Bandung: Remaja Rosda Karya, 2007) h. 6
} 


\section{AL-MARSHAD: JURNAL ASTRONOMI ISLAM DAN ILMU-ILMU BERKAITAN \\ ISSN 2442-5729 (print) || ISSN 2598-2559 (online) \\ http://jurnal.umsu.ac.id/index.php/almarshad \\ DOI: 10.30596/jam.v\% vi\%i.5251|| Vol. 6, No. 2 Desember 2020}

dalam penelitian. Purposive sampling adalah

salah satu teknik pengambilan sampel secara sengaja ${ }^{8}$, maksudnya peneliti menentukan sendiri sampel yang diambil yaitu mereka yang telah mempelajari ilmu falak di fakutas agama Islam yang kategori semesternya adalah sudah selesai semester tujuh.

Adupun subjek dalam penelitian ini adalah a). Pimpinan Fakultas Agama Islam sebagai sumber informasi data secara umum dan keseluruhan dalam kurikulum di fakultas Agama Islam, b). Dosen pengampu mata kuliah Ilmu Falak, sebagai pelaku yang berperan melaksanakan kegiatan atau proses pembelajaran di Fakultas Agama Islam c). Mahasiswa semester tujuh yaitu mereka yang sudah selesai mempelajari ilmu falak di Fakultas Agama Islam UMSU. Dimana jumlah responden dari mahaiswa ini sebanyak 51 orang yang terdiri dari laki-laki dan perempuan serta sebarannya dalam seluruh program studi yang ada di lingkungan Fakultas Agama Islam. Dimana mahasiswa ini merupakan sumber informasi dan sasaran pelaksanaan pembelajaran ilmu Falak di Fakultas Agama Islam. Adapun jumlah mahasiswa terdapat dalam Tabel. 1 berikut ini :

8 John w. Creswell, Reseach Design, (London : Sage, 2009) h. 112
Tabel 1 : Jumlah sebaran responden program studi di FAI UMSU

\begin{tabular}{|l|l|l|l|}
\hline \multirow{2}{*}{$\begin{array}{c}\text { Program } \\
\text { Studi }\end{array}$} & \multicolumn{2}{|l|}{ Jenis Kelamin } & Jumlah \\
\cline { 2 - 4 } & $\begin{array}{l}\text { Laki- } \\
\text { laki }\end{array}$ & Perempuan & \\
\hline $\begin{array}{l}\text { Pendidikan } \\
\text { Agama } \\
\text { Islam }\end{array}$ & 4 & 16 & 20 \\
\hline $\begin{array}{l}\text { Pendidikan } \\
\text { Islam Anak } \\
\text { Usia Dini }\end{array}$ & 0 & 6 & 6 \\
\hline $\begin{array}{l}\text { Perbankan } \\
\text { Syariah }\end{array}$ & 4 & 14 & 18 \\
\hline $\begin{array}{l}\text { Manajeman } \\
\text { Bisnis } \\
\text { Syariah }\end{array}$ & 2 & 6 & 8 \\
\hline Total & 10 & 41 & 51 \\
\hline
\end{tabular}

Dalam teknik pengumpulan data, penelitian ini menggunakan beberapa teknik pengumpulan data berupa; 1) Wawancara / Interview, pelaksaan ini dilakukan kepada dosen pengampu dan Pimpinan Fakultas dan pimpinan program studi. 2) Angket, Proses pemberian angket diberikan kepada 51 mahasiswa yang tersebar di fakultas agama Islam dari empat program studi, proses pemberian angket dilakukan dengan peberian angket online dengan google formulir; 3) Dokumentasi 9, yaitu mempelajari kurikulum dan hasil belajar

\footnotetext{
9 J.R. Raco, Metode Penelitian Kualitatif Jenis, karakteristik \& Keunggulan ,( Jakarta : Grasindo ,2010) h .112-116
} 


\section{AL-MARSHAD: JURNAL ASTRONOMI ISLAM DAN ILMU-ILMU BERKAITAN \\ ISSN 2442-5729 (print) || ISSN 2598-2559 (online) \\ http://jurnal.umsu.ac.id/index.php/almarshad \\ DOI: 10.30596/jam.v\% vi\%i.5251|| Vol. 6, No. 2 Desember 2020}

dari mahasiswa serta juga mempelajari dokumen berupa buku-buku referensi yang ada kaitannya dengan pembelajaran ilmu falak.

\section{Hasil dan Pembahasan}

\section{Pembelajaran Ilmu Falak}

Ilmu falak bisa dikatakan sebuah ilmu yang sudah langka dipelajari oleh manusia. Pernyataan ini dikarenakan alasan bahwa peminat untuk mengkaji ilmu ini bisa dikatakan sangat sedikit dibandingkan dengan ilmu-ilmu eksakta dan sosial yang lain. Jika dicari dari jumlah program studi tentang ilmu falak ini di Indonesia bisa ditemui hanya 5 (lima) program studi yang murni mempelajari ilmu falak di beberapa universitas di Indonesia.

Ilmu falak merupakan ilmu yang mempelajari tentang astonomi atau warisan ilmu pengetahuan yang sudah sangat tua dalam khazanah peradaban dunia untuk dipelajari oleh berbagai kalangan supaya tidak terjadi kepunahan dalam penyebaran ilmunya. Dalam khazanah Islam klasik, ragam istilah tentang ilmu falak ini sangatlah banyak sekali, diantara peristilahan tersebut adalah falak, nujum, hai'ah, miqat dan rasd. Intilah ini muncul dari beragam pengamatan yang di lakukan oleh manusia terhadap fenomena langit ${ }^{10}$.

Jika dilihat dari segi etimologi pengertian ilmu falak ini berasal dari dua kata yaitu $\mathrm{ilm}$ dan al-falak. Ilm artinya al-ma'rifah dalam pemaknaanya pengetahuan. Sedangkan alfalak artinya al-masdar yaitu orbit, garis, atau bisa juga dikatakan tempat perjalanan bintang ${ }^{11}$.

Ilmu falak jika ditinjau dari segi lughawi adalah ilmu yang mempelajari tata lintas pergerakan benda-benda langit khususnya bulan dan matahari dalam orbitnya sistematis dan ilmiah ${ }^{12}$. Atau secara sederhananya ilmu falak adalah ilmu pengetahuan tentang orbit, garis edar tempat beredarnya bintang dan planet-planet ${ }^{13}$.

Senada dengan penjelasan Arwin dan Watni penjelasan dari Mahyudin mengenai ilmu falak hampir sama hanya dengan menambahkan tujuan dari peredaran orbit itu supaya diketahui posisi benda langit tersebut antara satu dengan lainnya agar dapat diketahui waktu-waktu di permukaan bumi serta kedudukannya dari benda-benda

\footnotetext{
${ }^{10}$ Susiknan Azhari, Ilmu Falak Teori dan Praktik ( Yogyakarta : Lazuardi, 2001) h 3.

${ }^{11}$ Ahmad Warson Munawwar, Kamus Al-Munawwir Arab - Indonesia terlengkap, (Surabaya : Pustaka Progresif 2002), h 966.

${ }^{12}$ Arwin Juli Rakhmadi Butar-butar, Pengantar Ilmu Falak Teori, Praktik dan Fikih, ( Jakarta : Raja Grafindo Persada, 2018) h 1.

${ }^{13}$ Watni Marpaung, Pengantar Ilmu Falak, ( Jakarta : Kencana 2015) h 1.
} 


\section{AL-MARSHAD: JURNAL ASTRONOMI ISLAM DAN ILMU-ILMU BERKAITAN \\ ISSN 2442-5729 (print) || ISSN 2598-2559 (online) \\ http://jurnal.umsu.ac.id/index.php/almarshad \\ DOI: 10.30596/jam.v\% vi\%i.5251|| Vol. 6, No. 2 Desember 2020}

langit yang lain ${ }^{14}$.

Ilmu falak jika di lihat dalam bahasa Inggris maka akan di dapatkan istilah yang lain yaitu "Astronomi", adapun Asronomi adalah ilmu pengetahuan yang mempelajari benda-benda langit dengan tujuan untuk mengetahui pengaruh benda-benda langit itu terhadap nasib seseorang di muka bumi, maka astronomi juga bisa dikatakan dengan ilmu perbintangan, jika dikaitkan dengan Astrologi inilah yang dikenal pada masa sekarang ini dengan sebutan Ilmu Nujums 15. Lantas jika di amati secara spesifik apa yang dapat membedakan antara ilmu astonomi dengan ilmu falak?. Jika dikaji memang terdapat perbedaan yang signifikan antara ilmu falak dengan astronomi, diantaranya adalah jika dilihat dari sisi ruang lingkup pembahasanya, astronomi mengkaji seluruh benda-benda langit, baik matahari, palanet, satelit, bintang, galaksi, bulan dan lainnya. Sedangkan ilmu falak ruang lingkup pembahasannya hanya terbatas pada matahari,bumi dan bulan Itupun hanya posisinya saja sebagai akibat dari pergerakannya ${ }^{16}$.

\footnotetext{
${ }^{14}$ Muhyiddin Khazin, Ilmu Falak Teori dan Praktik, (Yogyakarta: Buana Pustaka, 2004), hlm.3.

${ }^{15}$ Salamun Ibrahim, Ilmu Falak, (Bandung: Pustaka Progresif, 1995), h. 39

${ }^{16}$ Jaenal Arifin, Dialektika Hubungan Ilmu Falak dan Penentuan Awal Ramadhan, Syawal, Dzulhijjah di Indonesia

(Sinergi Antara Independensi Ilmuwan dan Otoritas
}

Dari pemaparan berbagai ahli tentang pengertian ilmu falak maka bisa disimpulkan bahwa ilmu falak bisa juga disebut dengan ilmu astronomi walaupun pengkajian dari sisi ruang lingkup pembahasan sedikit berbeda dengan ilmu falak, namun memiliki sebuah persamaan mengenai pembahasan ilmu-ilmu yang berkaitan dengan benda-benda langit.

\section{Kurikulum Ilmu Falak di Fakultas}

\section{Agama Islam}

Seperti yang sudah dijelaskan pada butir pendahuluan bahwa di Fakultas Agama Islam Universitas Muhammadiyah Sumatera Utara tidak ada program studi ilmu falak, namun dalam kurikulum pembelajaran di Fakultas Agama Islam ada mata kuliah ilmu falak. Pembelajaran ilmu falak dilakukan di Fakultas Agama Islam pada semua program studi yang ada, diketahui bahwa program studi dilingkungan Fakultas Agama Islam Universitas Muhammadiyah Sumatera Utara sebanyak 4 program studi yaitu : Pendidikan Agama Islam, Pendidikan Islam Anak Usia Dini, Perbankan Syariah serta Manajemen Bisnis Syariah $^{17}$.

Mata kuliah ilmu falak di Fakultas Agama Islam merupakan kurikulum yang wajib diambil oleh semua mahasiswa, dalam

Negara), 2019, Jurnal Penelitian Volume 13, Nomor 1 Februari 2019, h 42

${ }^{17}$ www.umsu.ac.id / fai.umsu.ac.id 


\section{AL-MARSHAD: JURNAL ASTRONOMI ISLAM DAN ILMU-ILMU BERKAITAN \\ ISSN 2442-5729 (print) || ISSN 2598-2559 (online) \\ http://jurnal.umsu.ac.id/index.php/almarshad \\ DOI: 10.30596/jam.v\% vi\%i.5251|| Vol. 6, No. 2 Desember 2020}

pengertiannya mata kuliah ini merupakan mata kuliah wajib bukan mata kuliah pilihan, sehingga seluruh mahasiswa yang kuliah di Fakultas Agama Islam Universitas Muhammadiyah Sumatera Utara mempelajarinya. Adapun alasan Mata kuliah ini wajib bagi semua mahasiswa dikarenakan dari visi Fakultas Agama Islam yang berbunyi : "Menjadi Fakultas Agama Islam yang unggul dalam membangun peradaban bangsa dengan mengembangkan ilmu-ilmu keislaman, teknologi dan sumber daya manusia berdasarkan al-Islam dan Kemuhammadiyahan"18.

Berdasarkan visi dari Fakultas Agama Islam inilah muncul sebuah rencana yang harus di realisasikan, bagaimana lulusan dari Fakultas Agama Islam ini bisa unggul dalam membangun peradaban bangsa dengan mengembangkan ilmu-ilmu keislaman, teknologi dalam hal ini ilmu keislaman dan teknologi inilah ditafsirkan dengan mempelajari ilmu falak sebagai warisan khazanah keilmuan klasik dan menerapkan kepada kemodrenan pada zaman sekarang ini.

Selain dari visi ini fasilitas dari fakultas Agama Islam yang didukung dengan observatorium ilmu falak UMSU (OIF UMSU) menambah keyakinan dalam

\footnotetext{
${ }^{18}$ Rensra Fakultas Agama Islam 2015-2020
}

membuat kurikulum mata kuliah ilmu falak di fakultas agama Islam, sehingga setiap materi dalam pembelajaran ilmu falak ini bisa dilakukan praktek langsung di Observatorium Ilmu Falak yang terbangun megah dengan fasilitas berupa teropong angkasa dan peralatan yang nilainya sampai menelan pembiayaan milyaran rupiah.

Observatorium Ilmu Falak UMSU yang sudah menjadi kebanggaan institusi,Persyarikatan dan masyarakat umum ini jika tidak dimanfaatkan dengan sebaik mungkin rasanya sangatlah rugi sekali, sehingga mahasiswa yang telah mempelajari mata kuliah ilmu falak dan kemudian dengan serius memperdalam ilmunya bisa saja diberdayakan sebagai kader pelanjut dalam penguasaan ilmu falak bahkan diberdayakan menjadi karyawan di observatorium ini.

Kurikulum mata kuliah ilmu falak ini dirancang dengan begitu baik berdasarkan keilmuan dari mahasiswa. Artinya jika ada empat program studi di Fakultas Agama Islam ini maka akan disesuaikanlah kurikulumnya berdasarkan program studi yang mereka ampu. Misalkan jika mahasiswa Pendidikan Agama Islam dengan mahasiswa Perbankan Syariah maka materi pembelajarannya akan disesuaikan menurut program studinya. Sehingga materi yang 


\section{AL-MARSHAD: JURNAL ASTRONOMI ISLAM DAN ILMU-ILMU BERKAITAN \\ ISSN 2442-5729 (print) || ISSN 2598-2559 (online) \\ http://jurnal.umsu.ac.id/index.php/almarshad \\ DOI: 10.30596/jam.v\% vi\%i.5251|| Vol. 6, No. 2 Desember 2020}

diajarkan di program studi Pendidikan

Agama Islam dan Perbankan Syariah akan

berbeda. Ini mengacu kepada lulusan yang akan mereka dapatkan nantinya. Jika mahasisiwa pendidikan agama Islam pada identiknya mengarah kepada materi-materi pembelajaran PAI nya sedangkan bagi jurusan Perbankan Syariah mengarah kepada hitungan-hitungan.

Mahasiswa yang sudah masuk dalam pembelajaran Ilmu Falak memberikan beberapa komentar terkait pembelajaran ilmu falak di Fakultas Agama Islam. Respons mahasiswa yang sudah mengikuti perkuliahan ilmu falak bermacam-macam berdasarkan sebaran angket yang diberikan kepada mahasiswa tentang pembelajaran ilmu falak sebagai berikut :

Tabel 2 : Kesesuaian tentang Kurikulum Ilmu Falak di FAI UMSU

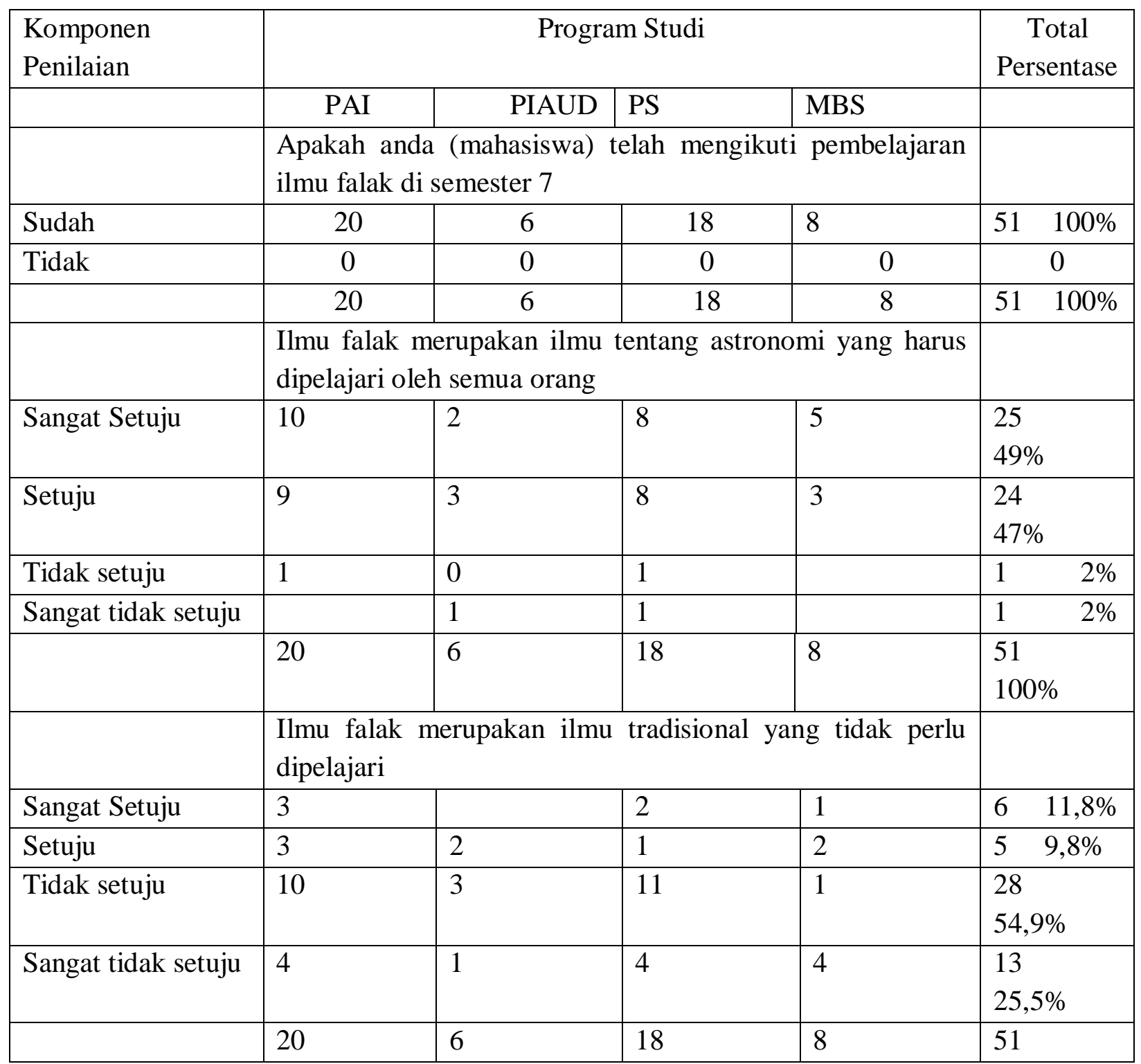


DOI: 10.30596/jam.v\% vi\%i.5251|| Vol. 6, No. 2 Desember 2020

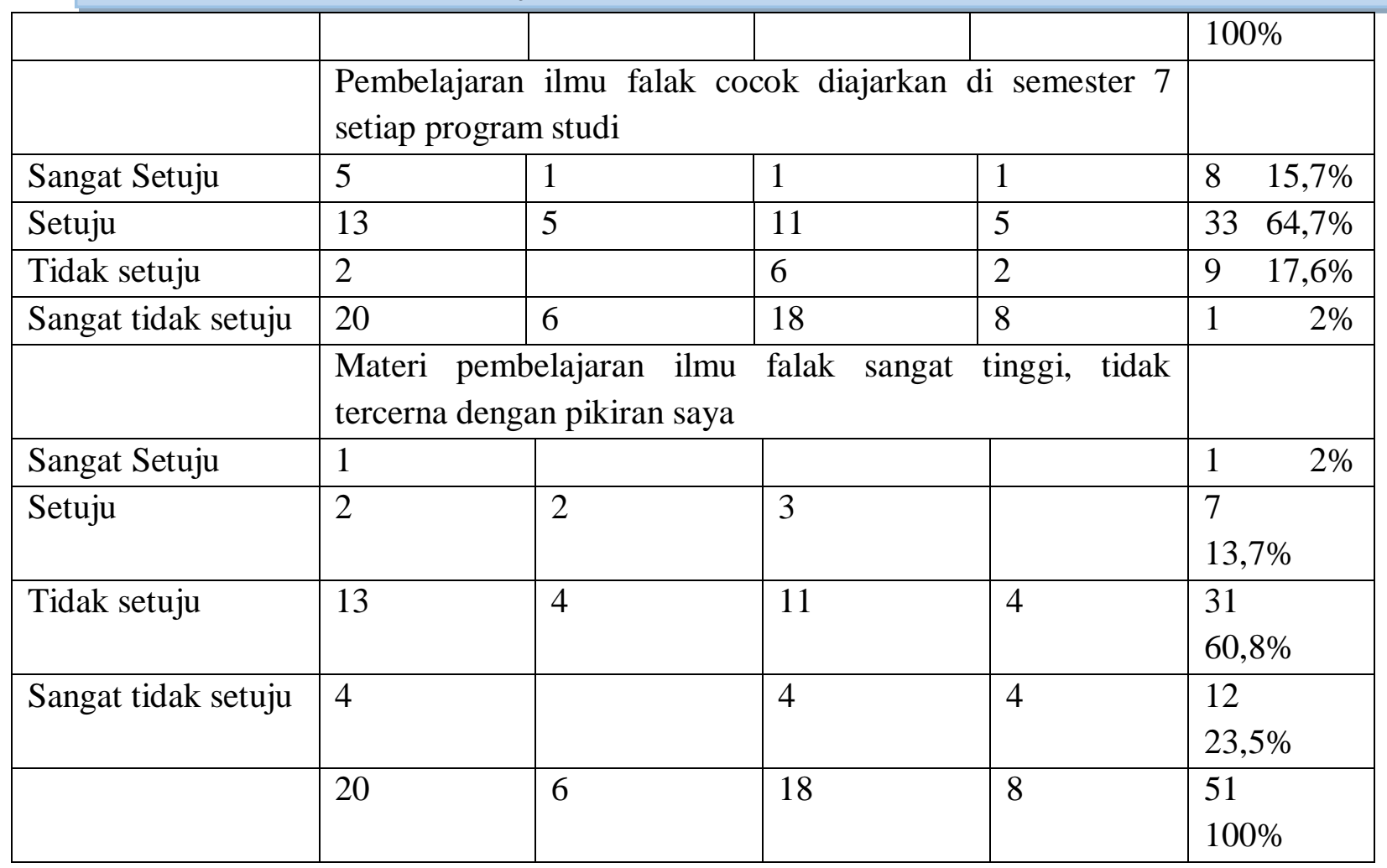

Pemaparan dari Tabel.2 tentang kurikulum menurut mahasiswa di Fakultas Agama Islam sangatlah cocok untuk dipelajari. Terbukti dari angket mahasiswa bahwa mereka sudah mempelajari ilmu falak pada semester tujuh dan semuanya mengatakan sudah pernah mengikuti mata pelajaran ilmu falak.

Dari pemaparan data berikutnya bisa diketahui bahwa pandangan mahasiswa di fakultas Agama Islam tentang mata kuliah ilmu falak sangatlah positif, dari pertanyaan tentang ilmu falak adalah ilmu astronomi yang harus dipelajari oleh seluruh orang, para mahasiswa ini sangat menyetujuinya terlihat hampir $80 \%$ mahasiswa ini menyarankan pembelajaran ilmu falak bagi setiap orang. Bahkan yang menariknya kurikulum ilmu falak ini bukanlah kurikulum yang dianggap pembelajaran tradisional yang tidak ada guna untuk mempelajarinya, jika dilihat data persentase bahwa terdapat hampir $85 \%$ mahasiswa ini tidak setuju dikatakan kurikulum ilmu falak merupakan kurikulum tradisional dan tidak perlu dipelajari.

Proses pemberian mata kuliah ilmu falak yag dilakukan rata-rata mahasiswa ini setuju bahwa kurikulum ilmu falak diberikan pada semester 7 untuk semua program studi yang ada di Fakultas Agama Islam UMSU. Walaupun dari beberapa mahasiswa menyarankan bahwa kurikulum 


\section{AL-MARSHAD: JURNAL ASTRONOMI ISLAM DAN ILMU-ILMU BERKAITAN \\ ISSN 2442-5729 (print) || ISSN 2598-2559 (online) \\ http://jurnal.umsu.ac.id/index.php/almarshad \\ DOI: 10.30596/jam.v\% vi\%i.5251|| Vol. 6, No. 2 Desember 2020}

ini jangan dipelajari pada semester tujuh akan tetapi di pelajari pada semester lima sehingga mereka bisa cepat mengamalkan dan mengetahui tentang pembelajaran ilmu falak ini dan bisa mengaplikasikannya dalam kehidupan sehari-hari.

Materi kurikulum Ilmu falakpun menurut para mahasiswa tidak terlalu berat bahkan semua program studi ini mengatakan bahwa materi ilmu falak bisa tercerna atau bisa diikuti pembelajarannya. Senada dengan ini dosen pengampu ketika dipertanyakan mengenai materi kurikulum ilmu falak mengatakan bahwa ada yang sudah bisa langsung mengikuti pembelajarannya dan ada juga yang belum mengetahui sama sekali, menurut dosen pengampu ini ada juga pengaruh dari asal mereka melanjut kemungkinan besar bukan dari jurusan agama, namun menurut dosen pengampu ini kurikulum yang dibuat merupakan kurikulum yang di rancang menurut program studi dari mahasiswa itu sehingga bisa disesuaikan dengan kemampuan mahasiswanya.

\section{Pembelajaran ilmu falak di} Fakultas Agama Islam.

Pembelajaran ilmu falak di Fakultas Agama Islam Universitas Muhammadiyah Sumatera Utara sudah berlangsung semenjak perubahan kurikulum KKNI. Dimana pembelajaran mata kuliah ilmu falak ini menjadi mata kuliah penciri dari Fakultas Agama Islam Universitas Muhammadiyah Sumatera Utara dibandingkan dengan yang lain yang ada di beberapa perguruan tinggi keislaman di lingkungan Sumatera Utara pada Khususnya dan secara nasional pada umumnya.

Mahasiswa diberikan dosen sesuai dengan kompetensinya yaitu dosen yang betul-betul pakar dan ahli dibidang ilmu falak. Tercatat bahwa nama dosen pengampu mata kuliah ilmu falak di fakultas Agama Islam UMSU ini adalah Dr. Arwin Juli Rakhmadi Butar-butar. MA. Jika dilihat dari titel akademiknya sudah sangat menyakinkan yaitu bergelar doktor, dan magister. Ketika dilihat dari frofil pengajar ilmu falak ini sangatlah memiliki keahlian dalam bidang ilmu falak itu sendiri, karena doktor yang ditempuhnya diselesaikan di perguruan tinggi terkenal di dunia yaitu Institut of Arab Reseach and Studies, Cairo Mesir.

Arwin panggilan akrap dosen pengampu ilmu falak ini merupakan alumnus S2 pada tahun 2009 dan S3 2012 di Institut of Arab Reseach and Studies, Cairo Mesir dengan jurusan dibidang FilologiAstronomi. Sekarang selain menjadi dosen ilmu Falak di Fakultas Agama Islam Arwin 


\section{AL-MARSHAD: JURNAL ASTRONOMI ISLAM DAN ILMU-ILMU BERKAITAN \\ ISSN 2442-5729 (print) || ISSN 2598-2559 (online) \\ http://jurnal.umsu.ac.id/index.php/almarshad \\ DOI: 10.30596/jam.v\% vi\%i.5251|| Vol. 6, No. 2 Desember 2020}

juga menjadi kepala Observatorium Ilmu

Falak (OIF UMSU) yang bermarkas di lantai tujuh gedung pascasarjana Universitas Muhammadiyah Sumatera Utara di jalan Denai Kota Medan. Jika dilihat dari curiculum vitae pengajarnya maka tidak diragukan lagi keilmuan yang dimilikinya untuk mengajarkan ilmu falak di Fakultas
Agama Islam Universitas Muhamamdiyah Sumatera Utara.

Selain pengajar ketertarikan mahasiswa terkait mata kuliah ilmu falak sangatlah tinggi ditandai dengan beberapa data dari angket berikut ini :

Tabel 3 : Pembelajaran Ilmu Falak di FAI UMSU

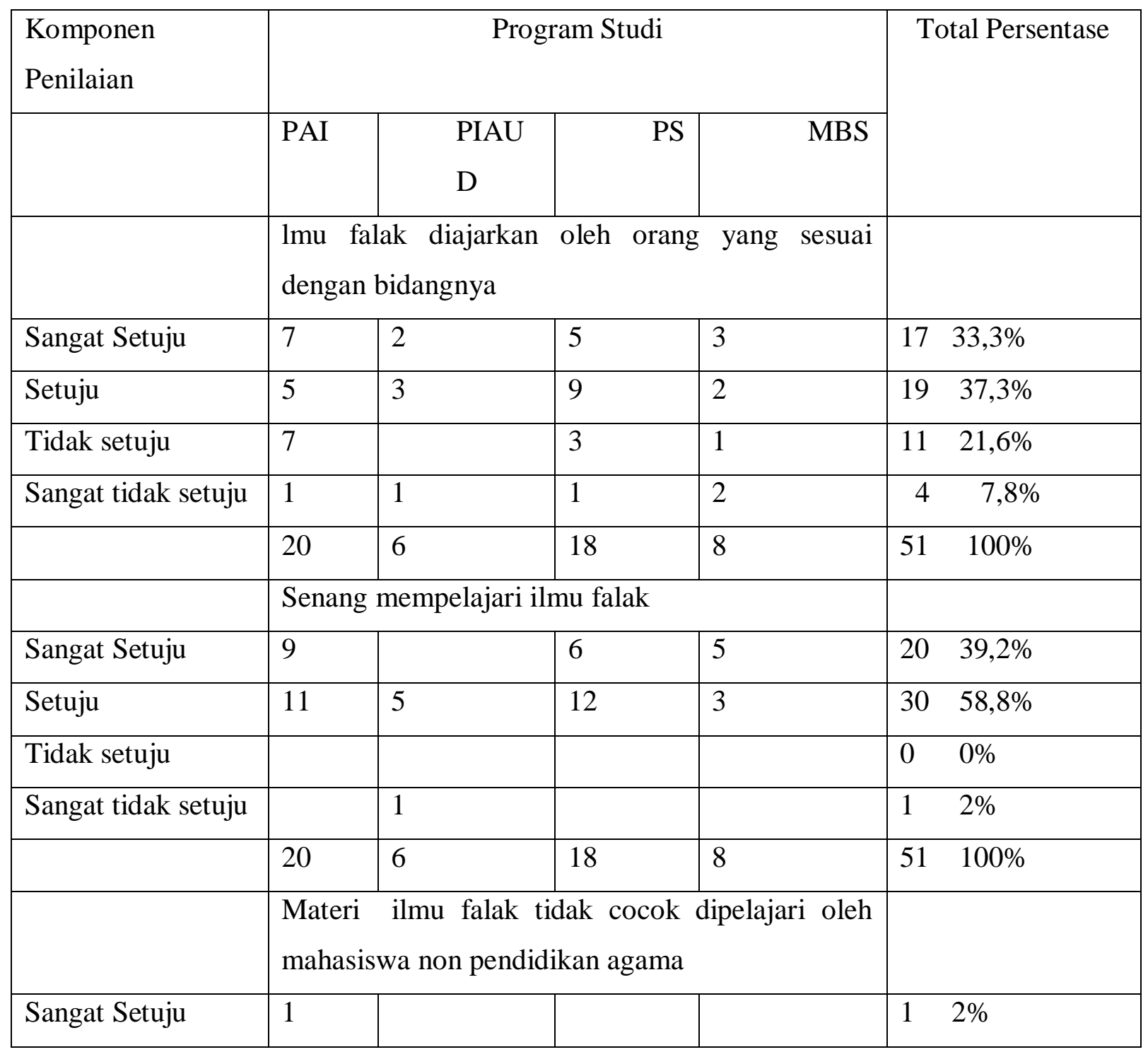


ISSN 2442-5729 (print) || ISSN 2598-2559 (online)

http://jurnal.umsu.ac.id/index.php/almarshad

DOI: 10.30596/jam.v\% vi\%i.5251|| Vol. 6, No. 2 Desember 2020

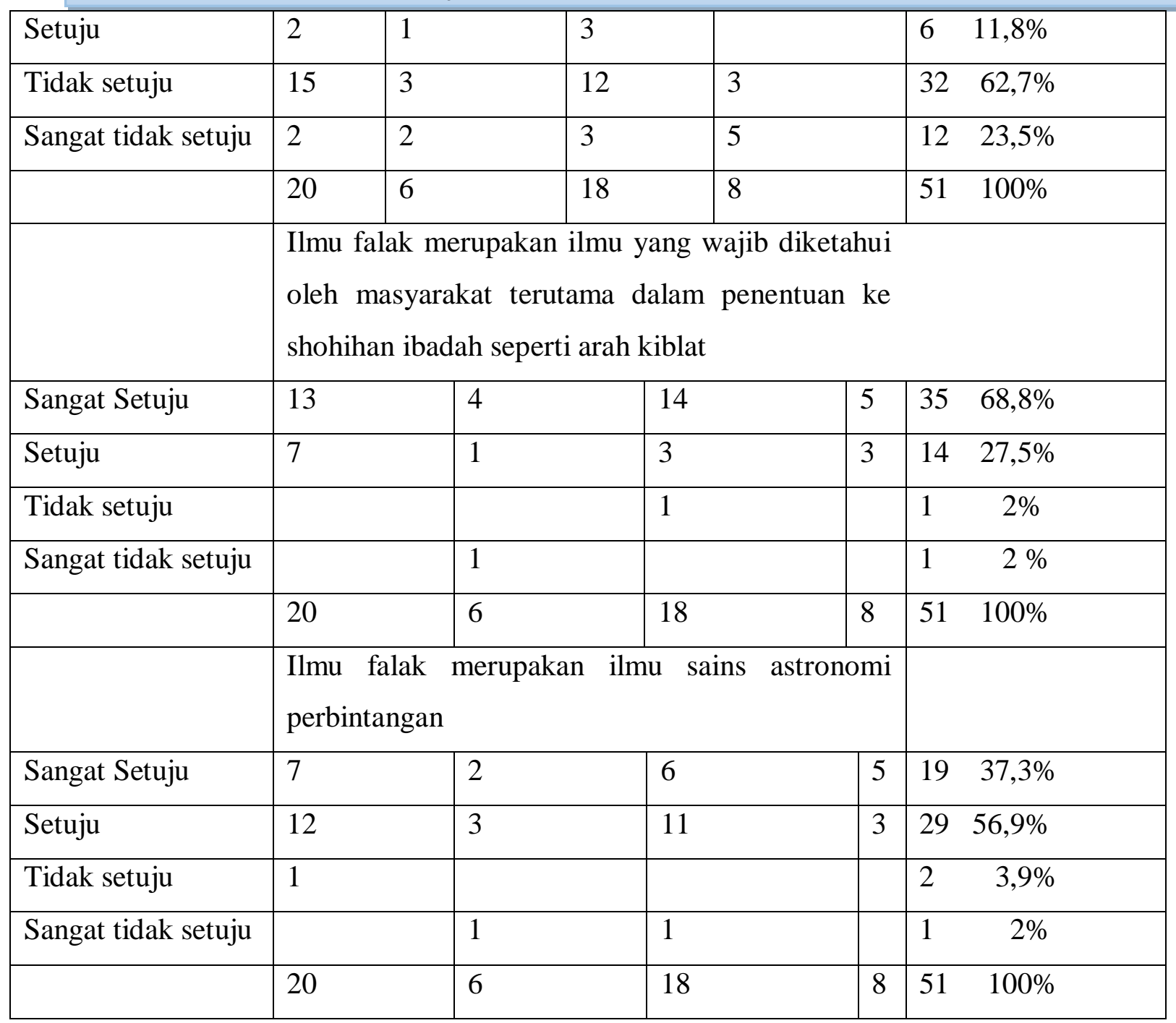




\section{AL-MARSHAD: JURNAL ASTRONOMI ISLAM DAN ILMU-ILMU BERKAITAN \\ ISSN 2442-5729 (print) || ISSN 2598-2559 (online) \\ http://jurnal.umsu.ac.id/index.php/almarshad \\ DOI: 10.30596/jam.v\%vi\%i.5251|| Vol. 6, No. 2 Desember 2020}

Pembelajaran mata kuliah Ilmu Falak di Fakultas Agama Islam Universitas Muhammadiyah Sumatera Utara sudah sangat bagus. Ditandai dengan pengajar (dosen) yang mengampu mata kuliah ini sesuai dengan bidangnya. Dalam proses pembelajaran yang berlangsung menurut dari para mahasiswa yang sudah belajar ilmu falak bahwa pengajar yang mereka rasakan sudah sesuai dengan bidang ilmu dosen tersebut, terlihat dalam angket mahasiswa mejawab hampir $80 \%$ dosen yang mengampu mata kuliah ini sesuai dengan bidangnya.

Mata kuliah ilmu falak merupakan mata kuliah yang disenangi oleh para mahasiswa terlihat dalam data angket mencapai $95 \%$ mahasiswa senang dalam mempelajari ilmu falak. Yang lebih menarik lagi bahwa hampir keseluruhan mahasiswa mengatakan bahwa ilmu falak ini wajib dipelajari oleh semua orang walaupun notabene bukan dari bidang fakultas agama Islam. Adapun alasan mereka mengatakan demikian dikarenaka menurut para mahasiswa ini, jika sudah mempelajari ilmu falak maka sedikit banyaknya mengetahui keshohihan dari pelaksanaan ibadah seperti pelaksanaan ibadah sholat terkait mengenai arah kiblat, waktu pelaksanaan sholat berupa jam masuknya waktu sholat dalam sholat lima waktu.

Pembelajaran ilmu falak ini sebesar 3 SKS di masing-masing program studi, diketahui bahwa lmu falak ini merupakan ilmu eksakta, walaupun demikian para mahasiswa menurut dosen pengampu relatif bisa mengikuti pembelajaran ini, namun jika sudah masuk kedalam materi hitung-hitungan maka sedikit banyaknya mahasiswa ini terkendala jika basic dasarnya mengenai matematika tidak ada.

Pembelajaran ilmu falak di Fakultas Agama Islam merupakan penambahan wawasan baru tentang keilmuan yang ada. Menurut dosen pengampu mata kuliah ini, pembelajaran ilmu falak ini ada plus dan minusnya, sehingga perlu ada penyederhanaan materi pembelajaran sehingga mahasiswanya lebih enjoy lagi dalam pembelajaran ilmu falak ini, misalnya menambah waktu praktek langsung baik itu mengukur arah kiblat, penentuan hisab dari setiap waktu permulaan bulan ditahun hijriah.

Seperti diketahui bahwa pembelajaran ilmu falak di Fakultas Agama Islam UMSU merupakan salah satu fakultas yang tidak ada program studi ilmu falak namun mempelajari mata kuliah ilmu falak, disinilah letak keunikan dari pembelajaran di Fakultas Agama Islam ini, ditambah lagi adanya observatorium yang bisa digunakan oleh para mahasiswa untuk praktek langsung. Sehingga 


\section{AL-MARSHAD: JURNAL ASTRONOMI ISLAM DAN ILMU-ILMU BERKAITAN \\ ISSN 2442-5729 (print) || ISSN 2598-2559 (online) \\ http://jurnal.umsu.ac.id/index.php/almarshad \\ DOI: 10.30596/jam.v\%vi\%i.5251|| Vol. 6, No. 2 Desember 2020}

pembelajaran ilmu falak disesuaikan dengan kebutuhan daripada mahasiswa dan proses pembuatan materi kurikulum dilakukan antara program studi dan dosen yang bersangkutan.

\section{Peranan pimpinan Fakultas dalam pengembangan Ilmu Falak di Fakultas Agama Islam} Pembelajaran ilmu falak di Fakultas Agama Islam Uniersitas Muhammmadiyah Sumatera utara tidak terlepas dari pemangku kebijakan di Fakultas Agama Islam UMSU terutama sekali pimpinan Fakultasnya yaitu Dekan dan para Wakil Dekan di Fakultas Agama Islam ini. Peranan pimpinan fakultas sangatlah tinggi terutama dalam pembuatan mata kuliah ilmu falak yang mana mata kuliah ini tidak pernah ada di Fakultas Agama Islam.

Perkembangan dan penyusunan kurikulum ketika adanya peninjauan kurikulum di Fakulatas Agama Islam UMSU akhirnya ada merubah kurikulum, yang salah satunya memasukkan mata kuliah ilmu falak di semua program studi yang ada di Fakultas Agama Islam sebagai penciri alumni Fakultas Agama Islam UMSU bisa mengukur dan menentukan arah kiblat. Selain itu keberadaaan observatorium ilmu falak juga menjadi landasan logis memasukkan mata kuliah ilmu falak di setiap program studi di Fakultas Agama Islam.

Melihat begitu penting peranan observatorium ilmu Falak yang sudah didirikan ini, membuat sebuah kebijakan baru dari Universitas dan Fakultas sesuai dengan rensra Universitas dan Fakultas adanya penambahan program studi baru di lingkungan Fakultas Agama Islam UMSU yang akhirnya pihak fakultas membuat program studi baru yaitu program studi ilmu falak (S1) yang sedang dalam pengajuan ijinnya kepada Kementrian Agama Republik Indonsesia.

Inilah peranan pimpinan fakultas dalam pelaksanaan pembelajaran ilmu falak, selain memasukkan mata kuliah dan juga membuat program studi baru yang bisa bersaing dengan program studi yang lainnya di lingkungan Fakultas Agama Islam.

\section{Kesimpulan}

Ilmu falak merupakan warisan khazanah intelektual muslim yang harus dipelihara keberadaan keilmuaannya jangan sampai punah ataupun orang tidak lagi mengetahuinya. Ilmu falak merupakan ilmu yang eksakta dan juga ilmu yang mempelajari tentang benda-benda langit berupa peredaran planet di langit antara lain bintang dan bulan serta benda-benda luar angkasa yang lainnya.

Fakultas Agama Islam UMSU walaupun tidak memiliki program studi ilmu falak namun memiliki mata kuliah ilmu falak 


\section{AL-MARSHAD: JURNAL ASTRONOMI ISLAM DAN ILMU-ILMU BERKAITAN \\ ISSN 2442-5729 (print) || ISSN 2598-2559 (online) \\ http://jurnal.umsu.ac.id/index.php/almarshad \\ DOI: 10.30596/jam.v\%vi\%i.5251|| Vol. 6, No. 2 Desember 2020}

yang mempunyai kurikulum resmi dan ini salah satu penciri dari fakulas Agama Islam . Mahaiswa sangat senang belajar ilmu falak, kurikulumya juga bisa diikuti oleh para mahasiswa. Dosen yang mengajar sudah memiliki kompetensi yang bagus yaitu bergelar Doktor dan tamatan dari luar negeri yaitu S2 (magister) dan S3 (doktor), pengampu mata kuliah ini tamatan dari Cairo Mesir dengan jurusan Astronomi. Peranan pimpinan fakultas terhadap keberadaan mata kuliah ilmu falak ini sangatlah tinggi. Dibuktikan dengan memasukkan mata kuliah ilmu falak dari tidak ada menjadi ada dan mempunyai bobot SKS sebanyak 3 yang keberadaannya menjadi penciri Fakultas.

\section{Daftar Pustaka}

Akrim, 2020 , Nilai-Nilai Pendidikan Islam dalam Observatorium, AlMarshad: Jurnal Astronomi Islam Dan Ilmu-Ilmu Berkaitan, Medan 2020

J.R. Raco,2010. Metode Penelitian Kualitatif Jenis, karakteristik \& Keunggulan, Jakarta : Grasindo.

Jaenal Arifin. 2019. Dialektika Hubungan Ilmu Falak dan Penentuan Awal Ramadhan, Syawal, Dzulhijjah di $\begin{array}{lrr}\text { Indonesia } & \text { (Sinergi } & \text { Antara } \\ \text { Independensi } & \text { Ilmuwan } & \text { dan }\end{array}$
Otoritas Negara),Jurnal Penelitian

Volume 13, Nomor 1 Februari 2019,

John W Creswell, Vicki L Plnao Clark. 2018.

Mendesain dan Melaksanakan Mixed Methods Research. Terjemah Ahmad Lintang (Yogyakarta : Pustaka Pelajar) John w. Creswell. 2009. Reseach Design, London : Sage.

Lexy. J. 2007. Moleong, Metode Penelitian Kualitatif, (Bandung: Remaja Rosda Karya.

Muhyidin Khazin. 2008. Ilmu Falak Dalam Teori dan Praktik. Yogyakarta: Buana Pustaka.

Salamun Ibrahim. 1995. Ilmu Falak, (Bandung: Pustaka Progresif.

Susiknan Azhari. 2004. Ilmu Falak Perjumpaan Khazanah Isam dan Sains Modern, $\quad$ Yogyakarta: Suara Muhammadiyah.

Syahril Rambe, Ali Imran Sinaga, Syaukani, 2019, Peranan Observatorium Ilmu Falak Umsu Dalam Pendidikan Islam Di Kota Medan, At-Tazakki: Vol. 3 No. 1 Januari - Juni 2019.

Yahya asy-Syami, ,1997, 'Ilm al-Falak, Beirut: Dar al-Fikr 'Arabi, 1997

www.umsu.ac.id / fai.umsu.ac.id Rensra Fakultas Agama Islam 2015-2020 